\title{
Helena Kadečková (14 August 1932 - 30 June 2018)
}

\author{
Helena Březinová
}

Helena Kadeckova, the doyen of Nordic Studies in Czechoslovakia and the Czech Republic, a distinguished scholar of Icelandic and Norwegian literature, died on 30 June 2018. She was 85 .

Helena Kadečková, my teacher and friend, once said in an interview that she was wondering how the heads of the Nordic states were going to fine her for not returning the medals she had received for her work as a scholar and for popularizing their literature. Among the many prizes she received during her life, three were from Scandinavia, and the letter accompanying each medal always included a request that the medals be returned after the death of the recipient. In 1991 she was awarded the Order of the Falcon by Iceland; in 1997 she received the Medal of St. Olav as a reward for advancing knowledge of Norway abroad; and in 2003 she was conferred the cross of a Knight $1^{\text {st }}$ Class of the Royal Norwegian Order of Merit.

Helena's wry remark on the fate of her awards portrays her in a nutshell. It reveals her typically subversive approach to worldly fame. Of course, she appreciated all those remarkable medals dearly, yet at the same time, she wanted to emphasize that what really mattered to her were her books, her students, and her readers. When asked by the interviewer, what she would do, then, about the returning clause, she replied that she had donated the medals to the National Museum in Prague, which had a comprehensive collection of medals, yet no Icelandic or Norwegian ones so far.

An educator for more than five decades, Docent Kadečková remained true to her alma mater, Charles University, in Prague, which she graduated from in 1957, as perhaps the darkest years of Communist political repression were about to end. She studied Danish, to begin with, but since she never really liked the language she soon switched to Norwegian, though ultimately finding her life's passion in Icelandic.

In 1957 Docent Kadečková had the good fortune to receive an Icelandic government scholarship. Her North Atlantic sojourn changed her life forever. Since that time, Icelandic literature became the primary object of her studies and she did more than anyone else to promote Iceland and its literature amongst Czechs and Slovaks. She was fascinated by the beauty and uniqueness of the stories that had been committed to vellum in medieval Iceland, and she provided her compatriots with Czech translations of some of the most important manuscripts from that period.

She translated the Prose Edda and the legendary Ynglinga saga from Old Norse in 1988, the year before the Communist regime in Czechoslovakia, like those in the rest of the Eastern bloc, collapsed. This volume was a revelation for Czechoslovak readers starving for good literature, which the Communist censors had administered 
in very small doses only. She also edited and adapted Ladislav Heger's translation of the Poetic Edda which the publishing house released in an impressive layout in 2004. Hence, the Czech reader is provided with an exquisite version of two milestones of Nordic literature in a translation faithful and informed, yet still truly poetic. In Czech, both the Prose Edda and the Poetic Edda bear witness to Helena Kadečková's methods and aims: her chief concern was not to produce another work solely for an elite circle of scholars; instead, she aimed at involving a wider audience and encouraging a dialogue between medieval texts and contemporary readers. This is why her translations of old Icelandic literature are superbly vivid and readable. At the same time, she never compromised when it concerned historical accuracy and she always drew on her immense erudition.

Further evidence of Helena's popularizing endeavours is her retelling of Norse Mythology in the volume Soumrak bohu (Twilight of the Gods, 1998). She did so in such a dazzling way that the book sold out and was reissued in 2018. In a popular Czech internet book database, the readers rate it at over 90 percent. One reader commented: 'Fascinating rendition of the stories from Norse mythology. I was immediately hooked and the read was breathtaking. I could not wait till the next chapter and was totally immersed. Thank you, Ms Kadečková :-).' In 2017, another reader remarked that this was the way a book on mythology should be written: 'Damn! This is mythology! Kadečková is a true expert in her field and her book is no cheap or light-weight version! I have to get her to sign my copy.' Yet anoth- er reader calls this translation a perfect gateway to the Poetic Edda. I am not sure whether Helena read any comments on the Internet whatsoever. I suspect she didn't, but I'm sure that especially this last remark would have pleased her immensely since she strived to open doors and the minds of the readers.

Helena Kadečková was not preoccupied with medieval literature only. She wrote her doctoral thesis on Icelandic Modernism, mentioning, among other works, Pórbergur Pórðarson's (1888/9-1974) A Letter to Laura (Bréf til Láru, 1924). Her main points and conclusions, which she presented in Iceland in the 1960s, have stood the test of time and are still cited. In 1965, she translated Pórðarson's recollections of his childhood, The Stones Speak (Steinarnir tala, 1956), a book that has attracted many Czech and Slovak readers, and later became something like the Holy Scripture for the Club of Icelandic Fanatics (Klub islandských fanatiku), whose members financed a reedition in 2004.

Helena was a true Íslandsvinur, friend of Iceland, translating giants like Pórbergur Pórdarson and the Nobel Laureate Halldór Laxness (1902-1998). Though she was friends with many of the authors she translated, she never consulted with them about the problems she ran into while translating. 'As a matter of principle,' she said, 'I do not ask the author when I have difficulties grasping the meaning since I know that when the book is published it begins to live a life of its own; the author is working on a new book and has forgotten all about the previous one. The work has to stand the test on its own.' 
Helena loved the mysterious ways art travels around the globe - just like the Icelanders who have always travelled far and wide since they settled on the island. When, in 1993, she translated Guðbergur Bergsson's novel The Swan (Svanurinn, 1991), a professor from the University of Reykjavík gave the Czech translation to Milan Kundera who at that time was visiting Iceland regularly. Kundera took a liking to the novel and recommended it to Gallimard. Soon Svanurinn was published in French.

Admirably, not one of the books Helena translated was trivial or shallow. She sought depth in life and literature, and to pass the sense of good literature on to generations of her students. Those who could cope with her merciless irony and even sarcasm, and appreciated her unprecedented and sometimes painful frankness, remained dedicated to the literature of the North. She trained several prolific translators who consulted her till her last days.

Helena Kadečková's began learning Nordic literature through Gunnar Gunnarsson's short novel Advent (1937), which was first translated into Czech in 1938. She loved the novel and decided to pay tribute to this masterpiece in a new translation, which was published in 2017. Symbolically, it turned out to be her very last translation. Of course, she translated it from Danish since Gunnarsson wrote it in this language. And she kept translating from Norwegian too. In recent years, her legs sometimes seized up, and, well aware of the importance of muscle neurons, she decided to exercise her brain translating Tarjei Vesaas (1897-1970) from Nynorsk (New Norwegian), which is not a piece of Bløtkake. Thanks to her persistence, Czech readers can now enjoy Vesaas's novel Bleikeplassen (The Bleaching Yard, 1946).

After she had decided to leave home for a hospice in June 2018, I spoke to Helena on the phone and she told me, 'You won't believe this but volunteers come to cheer us up! They are supposed to listen to our life stories. Well, there's no way I'm going to let them ask me questions! I am the one who is going to do the asking. And what interesting lives they have had! I am afraid my stay here is going to take longer than I expected. I like to observe life here. I learn so much about hospitals which I never thought about before.'

A lifelong passionate moviegoer and tireless exhibition-goer, Helena remained curious and open to new impressions to the end of her life. She loved to observe and study people. During her first stays in Iceland in the 1950s and the 1960s, she worked in fish factories and on sheep farms. She had great respect for the Icelandic farmers who face inhospitable nature, and for the Icelandic fishermen risking their lives at sea. After she begged them for hours, some fishermen even let her come on board, despite their reluctance, stemming in part from the old saying that a woman on board brings bad luck. She just wanted to see their work and the wild elements with her own eyes. And she learnt that 'the big fish are to be found deep down at the bottom'.

She demanded engagement and serious interest from her students. She herself was deeply engaged and serious in all her doings. She was admirably prepared 
to leave this world, stoically preparing ab- Cattle die, kinsmen die, solutely everything for that time. Helena The self must also die;

Kadečková is sorely missed, so let Od- But glory never dies, in's memento from Hávamál be a consola- For the man who is able to achieve it. tion to her friends, students, readers, and colleagues:

Cattle die, kinsmen die, The self must also die;

I know one thing which never dies:

The reputation of each dead man.

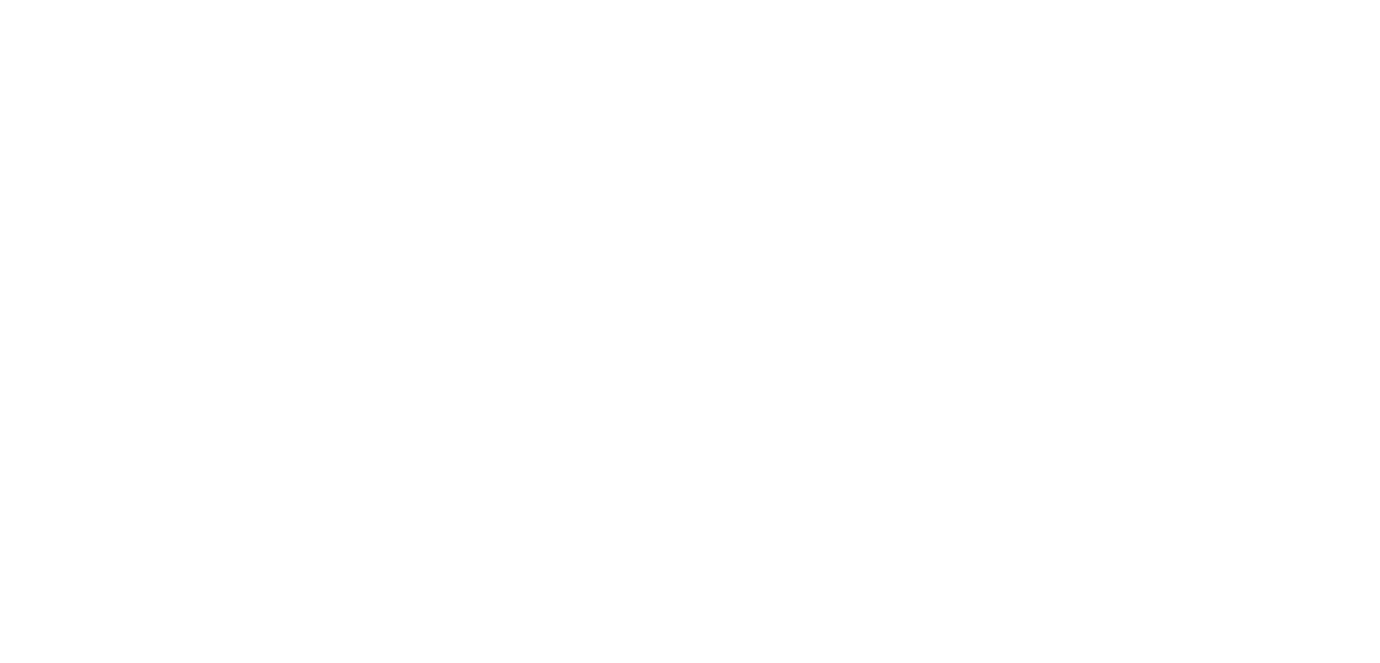

